\title{
ATTRACTIVENESS OF INFESTED AND UNINFESTED WHOLE WHEAT GRAIN AND COARSE WHEAT MEAL ODORS TO COLEOPTERAN STORAGE INSECT PESTS
}

\author{
Nikola J. Đukić ${ }^{*}$, Anđa B. Radonjić ${ }^{1}$, Goran G. Andrić ${ }^{2}$, Petar J. Kljajić ${ }^{2}$, Marijana P. Pražić Golić ${ }^{2}$ \\ ${ }^{1}$ University of Belgrade, Faculty of Agriculture, 11080 Belgrade, Nemanjina 6, Serbia \\ ${ }^{2}$ Pesticides and Environment Research Institute, 11080 Belgrade, Banatska 31b, Serbia
}

Corresponding author: Nikola Đukić

Phone: +381641872177

E-mail address: nikoladjukadj@yahoo.com

\begin{abstract}
Using a two-way olfactometer, the effects of the whole wheat grains and coarse wheat meal odors on the primary Sitophilus granarius (L.), S. oryzae (L.) and S. zeamais (Motch.) and secondary Tribolium castaneum (Herbst) and T. confusum (Du Val) stored-product pests behavior were examined. Whole wheat grains and coarse wheat meal were used in uninfested and infested form. Whole wheat grains were infested with $S$. oryzae adults and coarse wheat meal with $T$. castaneum adults. The odors of infested wheat grains depending on the insect species were 1.9 to 3 times more attractive than the uninfested wheat grains odors, except for the $T$. castaneum for whome the odors of infested and uninfested grains were equally attractive $(p=0.641)$. The greatest difference in the attractiveness of the infested and uninfested wheat grains odors was found for $T$. confusum ( 3 times longer in the arm with the odors of infested grain), and the smallest for $S$. granarius (1.9 times). We found that all primary and secondary stored-product pests, depending on the species, were 1.4 2.4 times more attracted to the odors of infested compared to the odors of uninfested wheat meal. The greatest difference in the atraction of infested and uninfested coarse wheat meal odors was recorded for the $T$. confusum, whose adults were 2.4 times longer in the arm with the odors of infested coarse wheat meal than in the arm with odors of uninfested wheat meal, while the smallest difference (1.4 times) was recorded for $S$. oryzae. The results of this study give a significant contribution to a better understanding of the storage insects behavior, which could be used in the design of new methods of monitoring of their presence in stored products.
\end{abstract}

Key words: Tribolium sp., Sitophilus sp., olfactometer, pest behaviour, food odours

\section{INTRODUCTION}

Stored-product insect pests inflict heavy damage on stored plant products intended for human and domestic animal consumption. It is estimated that the losses resulting from their activity at the annual level range from $9 \%$ in developed to> $20 \%$ in developing countries (Phillips and Throne, 2010). However, over $90 \%$ of all losses are due to the activity and feeding of primary pests (Rees, 2004). The storage insects are divided into two groups ac- cording to the diet: primary that attack and damage the whole grain and secondary that attack and damage already damaged grain and various grain products. Primary pests are usually developing inside the grain, whether the female lay the egg into the grain or on its surface, the first instar larvae enter the grains, feed and continue their development inside the grains, while the secondary feeders are developing outside the grain, feeding on the damaged 
grains, or grain products (Rees, 2004; Mahroof and Hagstrum, 2012; Mason and McDonough, 2012).

In addition to damaging whole grains and creating favorable conditions for infestation, primary pests also affect the behavior of secondary pests (Trematerra et al., 2015; Stevenson et al., 2017). In this context, in some previous studies it has been documented that odors of grain damaged by primary pests Sitophilus oryzae (L.), Sitophilus zeamais (Motch.) and Rhyzopertha dominica (F.), were significantly more attractive to secondary pests Oryzaephilus surinamensis (F.), Tribolium castaneum (Herbst) and Tribolium confusum Jackuelin du Val than the odors of mechanically damaged grains (Trematerra et al., 2000, 2015). However, the odors of uninfested stored products (whole or mechanically damaged grain) express different attractive potential for storage insects and significantly affect their behavior (Phillips et al., 1993; Trematerra et al., 1999). For example, the results obtained by Phillips et al. (1993) indicate that $S$. Oryzae and $T$. castaneum can quite differently respond to the same grain-related odors. On the other hand, Barrer (1983) found that whole grains of wheat added to the traps, beside Rhyzopertha dominica, attracted both Cryptolestes ferrugineus (Stephens) and T. castaneum.

Monitoring is a vital component of integrated pest management programs. Early stored-product pests detection is essential for the rational use of insecticides, safe storage of goods and protection of their quality. Sampling from commodity and traps are the most commonly used methods for monitoring insects in storage (Hagstrum et al., 1998). The advantage of the trap is that they allow early detection of initial infestation, and so far, aggregation and sexual pheromones are used as attractants in the traps (Hussain et al., 1994; Phillips, 1997; Hagstrum et al., 1998). In order to improve the attractive potential of the traps, laboratory, semi-field and field experiments showed that odor attractants from whole kernels, mechanically damaged kernels and insect damaged kernels or their combinations can improve potential of the traps and instead of capturing just one species or only one sex of the species, these components can be attractive for several species of storage insects (Phillips et al., 1993; Olsson, 2001; Wakefield et al., 2005; Stevenson et al., 2017). Athanassiou et al. (2016) found that in some cases, prior capture insects were more determinative than the presence of pheromone for trap performance. However, Athanassiou et al. (2017) found that relative cogeneric species, being present either dead or alive, may moderate trap performance. To our knowledge, the data available on the co-occurrence of relative species (species of the same genus) on behavioral interaction as well as between primary and secondary pests in the same comodity are few.

In this context, the intention of this study was to examine and compare the impact of whole wheat grain previously infested with $S$. oryzae and coarse wheat meal previously infested with $T$. castaneum on the primary $(S$. zeamais, $S$. oryzae and Sitophilus granarius (L.)) and secondary ( $T$. castaneum and $T$. confusum) pest beheviour.

\section{MATERIALS AND METHODS}

\section{Test insect}

In the tests we used laboratory populations of $S$. granarius, $S$. oryzae, $S$. zeamais, $T$. castaneum and $T$. confusum reared by the procedures described by Harein and Soderstrom (1966), and Bry and Davis (1985). Weevils, were reared in $2.5 \mathrm{~L}$ glass jars containing whole-grain soft wheat with moisture content below $12 \%$, while $S$. zeamais was reared on wholegrain maize with moisture content below $13 \%$. Tribolium species were reared in 2.5 $\mathrm{L}$ glass jars on white wheat flour with $5 \%$ yeast. Air temperature in the insectary was $25 \pm 1{ }^{\circ} \mathrm{C}$, and relative humidity $60 \pm 5 \%$. Unsexed 2-4 week old adults of all tested species were used and starved 24 hours before the experiment.

\section{Substrates used in the experiment}

In the experiment we used whole wheat grain NS $40 S$ variety and coarse wheat meal produced by milling whole wheat grains of the same variety. Uninfested substrates were prepared following the 
methods described by Đukić et al. (2016). Infested substrate were prepared following the modified methods described by Trematerra et al. (2015), by exposing whole wheat grain and coarse wheat meal to adults of $S$. oryzae and $T$. castaneum (5 adults per $1 \mathrm{~g}$ of the substrate), respectively. After 15 days insects were removed and substrates were kept in the laboratory on the room temperature for $24 \mathrm{~h}$ before used in the experiment.

\section{Olfactometer bioassay}

Modified four-arms olfactometer (Ninkovic et al., 2013) was used to test the effects of the uninfested and infested substrates odors on the insects' behavior. For both arms, plastic container with mesh lid was connected with tubes in order to allow undisturbed crossing of the air over the substrates. In the tubes, there was a filter (cotton wool and activated carbon) to purify the air, and thus prevent suction of the flour particles into the olfactometer. Air circulation was provided by a vacuum pump. The air crossed over the substrate and, together with its odors, entered the arms, and went to a central zone which was connected to the vacuum pump by a tube.

Experiments were performed in a darkened room with light just above the olfactometer to exclude the influence of all the other stimuli that could affect the behavior of the insects. One insect was placed in the central zone of the olfactometer and left for three minutes to adapt to the new environment. After adjusting, the insect position was recorded, for next 10 minutes, whether and how long it remained in one or the other arm. After each insect, the olfactometer was cleaned with $96 \%$ alcohol. Each experiment was done in 20 repetitions (one insect one repetition). After every repetition, in order to increase the reliability of the results, the containers with the substrates were rotated to the opposite side. We compared the $S$. granarius, $S$. oryzae, $S$. zeamais, $T$. castaneum and $T$. confusum preferences for odors from:

1. Uninfested versus whole wheat grains infested with S. oryzae

2. Uninfested versus coarse wheat meal infested with $T$. castaneum

\section{Data analysis}

Data of the length of the insect stay in one or the other olfactometer arm were statistically analyzed using the Wilcoxon pair test (StatSoft, 2011) setting a significance level of $P \leq 0.05$.

\section{RESULTS}

\section{Behavioral responses of primary and secondary storage pests to odors of uninfested and whole wheat grains infested with $S$. oryzae}

All tested insect species were statistically significantly more attracted to the odors of wheat grain infested with $S$. oryzae than the odors of uninfested grain, except for $T$. castaneum, which was equally attracted to odors of grain in both conditions ( $p=$ $0.641)$. Infested grain was equally more attractive for species $S$. oryzae, $S$. zeamais and $T$. confusum $(p=0.0001)$ and slightly weaker for $S$. granarius $(p=0.0004)$ compared to uninfested (Table 1).

Table 1.

Mean number of seconds \pm SE which insects spent in the arm with odors of infested and arm with uninfested whole wheat grains

\begin{tabular}{lccc} 
& \multicolumn{2}{c}{ Whole wheat grains } & \\
\cline { 2 - 3 } Insect species & Uninfested & Infested & $\mathbf{p}^{*}$ \\
\hline Sitophilus granarius & $124.50 \pm 12.78$ & $234.75 \pm 19.21$ & 0.0004 \\
Sitophilus oryzae & $109.50 \pm 14.67$ & $312.00 \pm 15.72$ & 0.0001 \\
Sitophilus zeamais & $104.00 \pm 9.55$ & $265.75 \pm 17.94$ & 0.0001 \\
Tribolium castaneum & $173.25 \pm 16.54$ & $212.25 \pm 24.08$ & 0.6407 \\
Tribolium confusum & $101.25 \pm 11.43$ & $305.25 \pm 29.83$ & 0.0001 \\
\hline
\end{tabular}

* Wilcoxon paired test, statistically significant deferences if $p \leq 0.05$ 
Nikola J. Đukić et al., Attractiveness of infested and uninfested whole wheat grain and coarse wheat meal odors to coleopteran storage insect pests, Food and Feed Research, 45 (2), 113-118, 2018

Table 2.

Mean number of seconds \pm SE which insects spent in the arm with odors of infested and arm with uninfested coarse wheat meal

\begin{tabular}{lccc}
\hline & \multicolumn{2}{c}{ Coarse wheat meal } & \multirow{2}{*}{$\mathbf{p}^{*}$} \\
\cline { 2 - 3 } Insect species & Uninfested & Infested & 0.0007 \\
\hline Sitophilus granarius & $143.50 \pm 14.20$ & $297.50 \pm 24.30$ & 0.0269 \\
Sitophilus oryzae & $176.00 \pm 10.89$ & $249.75 \pm 16.36$ & 0.0034 \\
Sitophilus zeamais & $145.25 \pm 11.01$ & $249.25 \pm 21.23$ & 0.0005 \\
Tribolium castaneum & $125.50 \pm 15.33$ & $289.75 \pm 22.76$ & 0.0007 \\
Tribolium confusum & $86.50 \pm 10.51$ & $207.25 \pm 22.54$ & \\
\hline
\end{tabular}

${ }^{*}$ Wilcoxon paired test, statistically significant deferences if $p \leq 0.05$

Behavioral responses of primary and secondary storage pests to odors of uninfested and coarse wheat meal infested with $T$. castaneum

All tested species were statistically significantly more attracted to the odors of coarse wheat meal infested with $T$. castaneum compared to the odors of uninfested coarse wheat meal. The most significant difference in the attractiveness of infested and uninfested coarse wheat meal was recorded for $T$. castaneum $(p=$ 0.0005 ), followed by $T$. confusum and $S$. granarius ( $p=0.0007)$. The least significant difference was recorded for $S$. oryzae $(p=0.0269)$ (Table 2).

\section{DIsCUSSION}

Depending on the insect species, the odors of the whole wheat grains infested with $S$. oryzae, attracted primary pests from 1.9 to 2.9 times more than the uninfested wheat grain odors. This is in line with the studies carried out by Trematerra et al. $(2007,2013)$, which have found that $S$. zeamais was 1.6 times more attracted to the odors of wheat grains infested with the same species than to the fresh uninfested wheat grain odors. Tribolium confusum was attracted 3 times more to the odors of the whole wheat grains infested with $S$. oryzae than to the uninfested wheat grains odors. Trematerra et al., (2000) came to very similar results, and found that the odors of whole wheat grains infested with $S$. oryzae was 3.2 times more attractive than the intact whole grains odors for the same species. However, it was surprising that in this experiment, $T$. castaneum, as a species of the same genus, did not show the preference for the wheat grains infested with primary pests over the uninfested wheat. This is opposite to the results of a study conducted by Trematerra et al., $(2000,2013)$ which have found that $T$. castaneum was statistically significantly more attracted to the odors of wheat grains infested with $S$. oryzae and $S$. zeamais than to the uninfested grains odors. However, recent studies have even determined the repellent effect of grains infested with $S$. granarius for $T$. castaneum (Stevenson et al., 2017). They explain this fact by the possibility that $T$. castaneum adults are seeking early infestations rather than potentially overcrowded late-stage infestations.

All tested primary and secondary pests were statistically significantly more attracted to the odors of coarse wheat meal infested with $T$. castaneum than to the uninfested coarse wheat meal odors. Although there is very little available data about behavior of secondary pests influenced by odors of food that is infested with the same group of pests, a high attraction of infested coarse wheat meal that attracted $T$. castaneum and $T$. confusum 2.3 and 2.4 times more, respectively than uninfested coarse wheat meal, was expected. Previous studies have found that secondary pests are more attracted by the odors of damaged, elderly and decaying grain and grain products than the odors of the fresh grains (Phillips, 1993; Cox and Collins, 2002; Athanassiou et al., 2017). By examining the intraspecific behavior of $T$. castaneum, Stevenson et al., (2017 ) have also found the attraction of the flavor infested with adults of this species for its larvae and adults. On the other hand, surprisingly high attraction of odors of coarse wheat meal infested with 
secondary pest for primary pests (1.4 to 2.1 times more attractive than uninfested), was unexpected. In contrast to our research Phillips et al. (1993) found that primary pests were more attracted to the fresh intact grain odors. However, recent studies conducted by Trematerra et al. (2015) have found that the primary pest (S. zeamais) was 1.5 and 1.8 times more attracted to the odors of the wheat grains infested with adults or larvae of $T$. castaneum than to the uninfested grains odors, which leads to the conclusion that the first colonizer can play the role of the primary colonizer.

\section{CONCLUSION}

The results of these studies showed the high attractiveness of infested substrates for primary and secondary pests and provide insight into the still insufficiently known stored-product insect pests behavior and their intraspecific and inter-specific interaction. The high attractiveness of the infested substrates can be used in the future to improve traps for monitoring the occurrence and number of these pests, but that would require further more detailed research.

\section{ACKNOWLEDGEMENTS}

This study was supported by the Ministry of Education, Science, and Technological Development of the Republic of Serbia (Project numbers: III 46012 and III 46008).

\section{REFERENCES}

1. Athanassiou, C., Kavallieratos, N., Campbell, J. (2016). Capture of Tribolium castaneum and Tribolium confusum (Coleoptera: Tenebrionidae) in floor traps: the effect of previous captures. Journal of Economic Entomology, 109, 461-466.

2. Athanassiou, C., Kavallieratos, N., Campbell, J. (2017). Effect of the presence of live or dead insects on subsequent captures of six storedproduct beetle species: the relative species matters. Journal of Economic Entomology, 110 (2), 770-775.

3. Barrer, P.M. (1983). A field demonstration of odour-based, host-food finding behaviour in several species of stored grain insects. Journal of Stored Products Research, 3 (19), 105-110.

4. Bry, R.E., Davis, R. (1985). Tribolium confusum and Tribolium castaneum. In Handbook of Insect Rearing vol. 1. Eds. R.F. Moore, Elsevier,
Amsterdam-Oxford-NewYork-Tokyo, pp. 291293.

5. Cox, P.D, Collins, L.E. (2002). Factors affecting the behaviour of beetle pests in stored grain, with particular reference to the development of lures. Journal of Stored Products Research, 38, 95-115.

6. Đukić, N., Radonjić, A., Lević, J., Spasić, R., Kljajić, P., Andrić, G. (2016). The effects of population densities and diet on Tribolium castaneum (Herbst) life parameters. Journal of Stored Products Research, 69, 7-13.

7. Hagstrum, D.W., Flinn, P.W., Subramanyam, B. (1998). Predicting insect density from probe trap catch in farm-stored wheat. Journal of Stored Products Research, 34, 251-262.

8. Harein, C.R., Soderstrom, E.L. (1966). Coleoptera infesting stored products. In Insect CoIonization and Mass Production. Eds. C.N. Smith, Academic Press, New York and London, pp. 241-257.

9. Hussain, A., Phillips, T.W., Mayhew, T.J., AliNiazee, M.T. (1994). Pheromone biology and factors affecting its production in Tribolium castaneum. $6^{\text {th }}$ International Working Conference on Stored Product, Canberra, Australia, Proceedings, pp. 533-536.

10. Mason, L.J., McDonough, M. (2012). Biology, behavior, and ecology of stored grain and legume insects. In Stored Product Protection. Eds. D.W. Hagstrum, T.W. Philips, G. Cuperus, Kansas State University, pp. 7-21.

11. Mahroof, M., Hagstrum, D.W. (2012). Biology, behavior, and ecology of insects in processed commodities. In Stored Product Protection. Eds. D.W. Hagstrum, T.W. Philips, G. Cuperus, Kansas State University, pp. 33-45.

12. Ninkovic, V., Dahlin, I., Vucetic, A., PetrovicObradovic, O., Glinwood, R., Webster, B. (2013). Volatile exchange between undamaged plants: A new mechanism affecting insect orientation in intercropping. PLoS One 8 (7): e69431. pmid:23922710.

13. Olsson, C. (2001). The Function of Food VoLatiles: Insect Behaviour and Pest Control, Tryck: Reprocentralen, Lunds Universitet, Lund.

14. Phillips T. W., Jiang, X.L., Brukholder, W.E., Phillips, J.K., Tran, H.Q. (1993). Behavioral responses to food volatiles by two species of stored-product coleoptera, Sitophilus oryzae (curculionidae) and Tribolium castaneum (tenebrionidae). Journal of Chemical Ecology, 19 (4), 723-734.

15. Phillips T.W. (1997). Semiochemicals of storedproduct insects: Research and applications. Journal of Stored Products Research, 33, 1720.

16. Phillips T.W., Throne E.J. (2010). Biorational approaches to managing stored-product insects. Annual Review of Entomology, 55, 375397.

17. Rees, D.P. (2004). Insects of Stored Products, CSIRO Publishing, Collingwood, Australia.

18. STATISTICA (Data Analysis Software System) (2011). v. 10., StatSoft, Inc., Tulsa, OK, USA.

19. Stevenson B.J., Cai, L., Faucher C., Michie M., Berna A., Ren Y., Anderson, A., Chyb S., Xu 
Nikola J. Đukić et al., Attractiveness of infested and uninfested whole wheat grain and coarse wheat meal odors to coleopteran storage insect pests, Food and Feed Research, 45 (2), 113-118, 2018

W. (2017). Walking responses of Tribolium castaneum (Coleoptera: Tenebrionidae) to its aggregation pheromone and odors of wheat infestations. Journal of Economic Entomology, 110 (3), 1351-1358.

20. Trematerra, P., Fontana, F., Mancini, M., Sciarretta, A. (1999). Influence of intact and damaged cereal kernels on the behaviour of rice weevil, Sitophilus oryzae (L.) (Coleoptera: Curculionidae). Journal of Stored Products Research, 35, 265-276.

21. Trematerra, P., Sciarreta, A. Tamasi, E. (2000). Behavioural responses of Oryzaephilus surinamensis, Tribolium castaneum and Tribolium confusum to naturally and artificially damaged durum wheat kernels. Entomologia Experimentalis et Applicata, 94, 195-200.

22. Trematerra, P., Valente, A., Athanassiou, C.G., Kavallieratos, N.G. (2007). Kernel interactions and behavioral responses of Sitophilus zeamais Motschulsky (Coleoptera: Curculionidae). Applied Entomology and Zoology, 42, 129-135.

23. Trematerra, P., laniro, R. Athanassiou, C., Kavallieratos, N. (2013). Behavioral responses of Sitophilus zeamais Motschulsky adults to conditioned grain kernels. Journal of Stored Products Research, 53, 77-81.

24. Trematerra, P., Athanassiou, C., Kavallieratos, N. (2015). Behavioral interactions between Sitophilus zeamais and Tribolium castaneum: the first colonizer matters. Journal of Pest Science, 88 (3), 573-581.

25. Wakefield, M.E., Bryning, G.P., Chambers, J. (2005). Progress towards a lure to attract three stored product weevils, Sitophilus zeamais Motschulsky, S. oryzae (L.) and S. granarius (L.) (Coleoptera: Curculionidae). Journal of Stored Products Research, 41, 145-161.

\title{
АТРАКТИВНОСТ МИРИСА ИНФЕСТИРАНЕ И НЕИНФЕСТИРАНЕ ПШЕНИЦЕ У ЗРНУ И ПРЕКРУПЕ ЗА СКЛАДИШНЕ ТВРДОКРИЛЦЕ
}

\author{
Никола Ј. Ђукић ${ }^{*}$, Анђа Б. Радоњић ${ }^{1}$, Горан Г. Андрић ${ }^{2}$, Петар Ј. Кљајић ${ }^{2}$, Маријана П.
} Пражић Голић ${ }^{2}$

\footnotetext{
${ }^{1}$ Универзитет у Београду, Пољопривредни факултет, 11080 Београд, Немањина 6, Србија

${ }^{2}$ Институт за пестициде и заштиту животне средине, 11080 Београд, Банатска 31б, Србија
}

Сажетак: Помоћу двокраког олфактометра испитиван је утицај мириса пшенице у зрну и пшеничне прекрупе на понашање примарних штеточина Sitophilus granarius (L.), Sitophilus oryzae (L.) и Sitophilus zeamais (Motch) и секундарних штеточина Tribolium castaneum (Herbst) и Tribolium confusum (Du Val). Пшеница у зрну и пшенична прекрупа коришћени су у неинфестираном и инфестираном облику, с тим да су зрна пшенице била инфестирана адултима S.oryzae а прекрупа адултима $T$. castaneum. Мирис инфестиране пшенице у зрну је био у зависности од инсекатске врсте од 1,9 до 3,0 пута атрактивнији од мириса неинфестиране пшенице, осим за адулте $T$. castaneum за које је био подједнако привлачан $(p=0,641)$. Највећа разлика у атрактивности мириса инфестиране и неинфестиране пшенице је забележена код $T$. confusum (3 пута више времена у краку са мирисом инфестираног зрна), а најмања код $S$. granarius (1,9 пута). Све примарне и секундарне штеточине су у зависности од врсте биле од 1,4 - 2,4 пута више привучене мирисом инфестиране, него мирисом неинфестиране пшеничне прекрупе. Највећа разлика у атрактивности мириса инфестиране и неинфестиране прекрупе, утврђена је код $T$. confusum, чији су адулти провели 2,4 пута више времена у краку са мирисом инфестиране прекрупе него у краку са мирисом неинфестиране, а најмања разлика $(1,4$ пута) забележена је код S.oryzae. Резултати ових истраживања дају значајан допринос бољем познавању понашања складишних инсеката, што би могло да се употреби у осмишљавању новог начина праћења њиховог присуства у ускладиштеним производима. хране

Кључне речи: Tribolium sp., Sitophilus sp., олфрактометар, понашање штеточина, мириси

Received: 25 September 2018

Received in revised form: 15 November 2018

Accepted: 27 November 2018 